Limnological Review (2011) 11, 2: 69-79

DOI 10.2478/v10194-011-0028-y

\title{
Cyanobacterial blooms in shallow lakes of the Iławskie Lake District
}

\author{
Ewa Dembowska \\ Department of Hydrobiology, Institute of Ecology and Environment Protection, Nicolaus Copernicus University, \\ Gagarina 9, 87-100 Toruń, Poland, e-mail: dembow@umk.pl
}

\begin{abstract}
The dominance of blue-green algae observed in many lakes is related to a high trophic level. Shallow eutrophic lakes are particularly often abundant in blue-green algae. The research on phytoplankton, the results of which are presented in this paper, was carried out between 2002 and 2005 in six lakes. These lakes differed considerably in their size and management methods applied in the catchment (drainage) area. A few types of water blooms were distinguished, which is related to the catchment area management, the intensity of mixing and the trophic level. Algal blooms of the Planktothrix type appeared in lakes situated in an open area of agricultural catchment basins. Algal blooms of the Limnothrix type were characteristic of lakes with a forest-agricultural catchment area but surrounded by high shores, which reduced the wind influence on the mixing. Sporadic mixed algal blooms were typical of lakes situated in forest catchment areas.
\end{abstract}

Key words: Blue-green algae, cyanobacteria, water bloom, phytoplankton, shallow lakes, turbulent species

\section{Introduction}

Algal blooms in inland waters are a frequently observed phenomenon occurring constantly in lakes with extremely high trophy (poly- and hypertrophy), or periodically in less fertile lakes. Special attention is given to water blooms of Cyanobacteria. The success of blue-green algae in many aquatic ecosystems is possible due to the high flexibility of this group in relation to changes in environmental parameters, such as temperature, $\mathrm{pH}$ or salinity (Reynolds et al. 1987). This group of organisms is particularly distinctive due to the cosmopolitan distribution and potential toxicity of some species, which create problems for human health and the environment (Berg et al. 1987; Carmichael 1994, 1996; Codd 2000).

Phytoplankton blooms are a typical phenomenon of shallow and over-eutrophicated water bodies. According to the concept of "alternative stable states" by Scheffer \& Jeppesen (1998), such lakes are characterised by little water transparency. Plankton algae are the main primary producer, and their usual mass development results in high water turbidity, which consequently leads to a self-shading effect. In a turbid environment, the development of submerged vegetation is limited by poor light availability. Wind mixing disturbs short-term stagnation. Sediments are more frequently resuspended here, mainly as a result of wave motion, which brings about a further increase in turbidity. Resuspension of bottom sediments can lead to sudden, but short-term (pulsatory) enrichment of the pelagic zone with nutrients. Due to the lack of rooted vegetation, zooplankton is exposed to strong pressure from fish, and this in turn affects the further development of phytoplankton. According to Wallace et al. (2000), Mischke (2003), as well as Mischke \& Nixdorf (2003), phytoplankton communities of very shallow $\left(z_{\max }<5 \mathrm{~m}\right)$ eutrophic lakes are often dominated by blue-green algae. Cyanobacteria have several, potentially important adaptations, which fa- 
cilitate their functioning in the changing environmental conditions that prevail in shallow eutrophic lakes (Wallace et al. 2000).

The present paper aims at evaluating the species composition and the biomass of blue-green algae forming water blooms in several shallow lakes of the Iławskie Lake District, which are located in different types of drainage basin. Based on the analyses of the cyanobacterial community, an attempt was undertaken to evaluate the relationship between the species composition and the abundance of this group, and the trophic status and the management methods applied in the drainage basin.

\section{Material and methods}

The research covered six lakes from the territory of the Iławskie Lake District: Gardzień, Iławskie, Kolmowo, Silm, Stęgwica and Tynwałdzkie. Two lakes - Iławskie and Tynwałdzkie - belong to the drainage basins of the River Iławka, the others: Gardzien, Kolmowo, Silm and Stęgwica - to the drainage basin of the upper River Osa. The studied lakes are located within a short (max. several kilometres) distance from the town of Iława. A small depth is typical of these water bodies (the maximum less than $6 \mathrm{~m}$, and the average from 1.1 to $3.1 \mathrm{~m}$ ). Morphometric (Jańczak 1997) and physicochemical data of the lakes are presented in Tables 1 and 2.

Table 1. Morphometric data on the lakes in the Iławskie Lake District (after Jańczak 1997)

\begin{tabular}{|c|c|c|c|c|c|c|}
\hline \multirow{2}{*}{ Morphometric data } & \multicolumn{6}{|c|}{ Lake } \\
\hline & Gardzień & Iławskie & Kolmowo & Silm & Stęgwica & Tynwałdzkie \\
\hline Latitude & $53^{\circ} 40^{\prime} 4^{\prime \prime} \mathrm{N}$ & $53^{\circ} 35^{\prime} 5^{\prime \prime} \mathrm{N}$ & $53^{\circ} 40^{\prime} 0^{\prime \prime} \mathrm{N}$ & $53^{\circ} 36^{\prime} 2^{\prime \prime} \mathrm{N}$ & $53^{\circ} 38^{\prime} 4^{\prime \prime} \mathrm{N}$ & $53^{\circ} 39^{\prime} 4^{\prime \prime} \mathrm{N}$ \\
\hline Longitude & $19^{\circ} 33^{\prime} 4^{\prime \prime} \mathrm{E}$ & $19^{\circ} 36^{\prime} 7^{\prime \prime} \mathrm{E}$ & $19^{\circ} 28^{\prime} 2^{\prime \prime} \mathrm{E}$ & 19०31'1"E & $19^{\circ} 32^{\prime} 2^{\prime \prime} \mathrm{E}$ & 19³8'1"E \\
\hline Area $\left[\mathrm{km}^{2}\right]$ & 0.86 & 1.55 & 0.43 & 0.59 & 0.40 & 0.30 \\
\hline Volume $\left[\mathrm{hm}^{3}\right]$ & 1.02 & 1.77 & 1.34 & 1.20 & 0.48 & 0.54 \\
\hline Maximum length [m] & 4175 & 3700 & 1050 & 1625 & 1880 & 1090 \\
\hline Maximum width [m] & 350 & 750 & 550 & 800 & 290 & 615 \\
\hline$z_{\max }[\mathrm{m}]$ & 2.1 & 2.8 & 5.7 & 3.7 & 1.7 & 2.6 \\
\hline$z[\mathrm{~m}]$ & 1.2 & 1.1 & 3.1 & 2.0 & 1.2 & 1.8 \\
\hline
\end{tabular}

Table 2. Physicochemical properties of the lakes' water

\begin{tabular}{|c|c|c|c|c|c|c|}
\hline \multirow{2}{*}{ Parameter } & \multicolumn{6}{|c|}{ Lake } \\
\hline & Gardzień & Iławskie & Kolmowo & Silm & Stęgwica & Tynwałdzkie \\
\hline SD visibility [m] & $0.6(0.3-1.4)$ & $0.8(0.5-1.3)$ & $0.7(0.3-1.0)$ & $1.4(0.8-2.1)$ & $0.9(0.5-1.4)$ & $0.5(0.3-1.0)$ \\
\hline $\mathrm{pH}^{\mathrm{a}}$ & 9.0 & $8.4-8.9$ & $7.6-9.1$ & n.d. & $7.2-8.6$ & $8.0-9.5$ \\
\hline $\mathrm{EC}\left[\mu \mathrm{S} \cdot \mathrm{cm}^{-1}\right]$ & $172(158-188)$ & $349(322-444)$ & $383(360-412)$ & $369-435$ & $197(166-213)$ & $284(242-335)$ \\
\hline $\mathrm{Chl} a\left[\mu \mathrm{g} \cdot \mathrm{l}^{-3}\right]$ & $40(21.9-73.2)$ & $23.7(12.1-35.3)$ & $47(19.2-105.3)$ & $8.8(6.2-11.2)$ & $11.6(6.5-14.7)$ & $60(41.6-111.4)$ \\
\hline $\mathrm{TN}\left[\mu \mathrm{g} \cdot \mathrm{I}^{-3}\right]^{\mathrm{a}}$ & 2950 & 2120 & 2040 & 1890 & 3200 & 2380 \\
\hline $\operatorname{TP}\left[\mu \mathrm{g} \cdot \mathrm{l}^{-3}\right]^{\mathrm{a}}$ & 28 & 128 & 112 & 68 & 36 & 80 \\
\hline $\mathrm{N}: \mathrm{P}$ & 105 & 17 & 18 & 28 & 89 & 30 \\
\hline TSI SD & 67 & 63 & 65 & 55 & 62 & 70 \\
\hline TSI chl a & 67 & 62 & 68 & 52 & 55 & 71 \\
\hline TSI TP & 52 & 74 & 72 & 65 & 56 & 67 \\
\hline TSI TN & 70 & 65 & 65 & 64 & 71 & 67 \\
\hline TSI average & 64 & 66 & 68 & 59 & 61 & 69 \\
\hline
\end{tabular}

a - measurements taken only once in the summer

n.d. - no data available 
The research was carried out in 2002-2005 in each lake for two consecutive seasons, except for Lake Iławskie where the research was conducted for only one year. The material for the studies was collected from one site situated in the central part of each lake. Samples were usually collected every month during the growing season and only once during winter. Several physicochemical parameters were determined in the lake water: Secchi disk visibility, temperature, $\mathrm{pH}$ and electrolytic conductivity. Water was collected for the analyses of the chlorophyll $a$ content. One time during the summer, the water was collected for the analyses of the nitrogen and phosphorus content.

For qualitative studies, the material was collected with a plankton net with a mesh diameter of ca. 55 $\mu \mathrm{m}$ from the whole water column. Samples were preserved with formaldehyde. For quantitative analyses, the material was collected at a depth of ca. $0.5 \mathrm{~m}$. This material was not thickened. Quantitative samples were preserved with Lugol's solution ( $\mathrm{J}$ in KJ). The count of algae was determined with Utermöhl's method (1958), the biomass by the volumetric method. The content of chlorophyll $a$ was analysed with Nusch's method (1980). Standard methods of analyses were applied for the determination of the concentration of biogenic substances (Hermanowicz et al. 1999).

Based on the Secchi disc visibility, the concentration of chlorophyll $a$ and the concentration of total phosphorus, the trophic state index was calculated: TSI SD, TSI chl $a$, TSI TP (Carlson 1977; Carlson \& Simpson 1996), and based on the concentration of total nitrogen, the trophic state index TSI TN of Kratzer \& Brezonik (1981).

\section{Results and discussion}

During the summer months, the SD visibility in Lakes Kolmowo, Gardzień and Tynwałdzkie was only $0.3 \mathrm{~m}$. Lake Tynwałdzkie was already investigated more than 30 years ago by Bogaczewicz-Adamczak (1978) and Rejewski (1979), and later by Luścińska \& Dogadalska (1993). Water-transparency values recorded previously in this lake in the spring-summer season were similar to the present-day results and ranged from $0.3-0.5 \mathrm{~m}$. The minimum value of water transparency in Lakes Stęgwica and Iławskie was 0.5 $\mathrm{m}$, whereas in Lake Silm, $0.8 \mathrm{~m}$.

All the investigated lakes were characterised by alkaline $\mathrm{pH}$. The lowest $\mathrm{pH}-7.2$ - was recorded in Lake Stęgwica, the highest $\mathrm{pH}-9.5$ - in Lake
Tynwałdzkie. Electrolytic conductivity was also heterogeneous - from $160 \mu \mathrm{Scm}^{-1}$ in Lake Gardzień to almost $450 \mu \mathrm{Scm}^{-1}$ in Lake Iławskie. The conductivity recorded in Lake Gardzien is characteristic of lakes with a moderate trophic state. All measured physicochemical parameters are presented in Table 2.

In the studied lakes, the presence of 54 taxa of blue-green algae was recorded (Table 3 ). The largest number of species - 38 - occurred in Lake Gardzień, the least - 17 species - in Lake Iławskie. The presence of the following eight species was recorded in all the lakes: Aphanizomenon flos-aquae, Aphanocapsa incerta, Microcystis aeruginosa, Microcystis viridis, Microcystis wesenbergii, Planktolyngbya limnetica, Pseudanabaena limnetica, Woronichinia naegeliana. Most of the recorded species of blue-green algae are planktonic forms (31 taxa), 19 species are sedentary (benthic, periphytonic) or metaphytonic forms. Also one endogleic and one aerophytic species was recorded.

The occurrence of water blooms results from excessive eutrophication, which may even assume the form of pollution. Algal blooms lead to excessive production of organic matter posing a threat to the remaining part of the biocenosis of the water body (Bucka \& Wilk-Woźniak 2005). Bucka (1987) quotes, after different authors, the criteria determining the water bloom, i.a. the number of algae amounting to $10^{4}-10^{6}$ specimens perml ${ }^{-1}$, biomass $1-5 \cdot 10^{2} \mathrm{mg}^{-1}$, or even only $10 \mathrm{mg} \cdot \mathrm{l}^{-1}$, and the average biomass within the range of $10-30 \mathrm{mgl}^{-1}$. During algal blooms, water transparency decreases below $1 \mathrm{~m}$ (the value measured as Secchi disk visibility). The concentration of chlorophyll $a$ in the water during algal blooms exceeds 50 $\mu \mathrm{g} \cdot \mathrm{l}^{-1}$.

Bucka (1987) also lists species capable of creating water blooms. The following species of blue-green algae can do so: Microcystis aeruginosa, M. wesenbergii, M. viridis, Limnothrix planctonica, Planktolynbya limnetica, Planktothrix agradhii, Aphanizomenon gracile, and Anabaena oscillarioides. Reynolds (2006) reports that plankton algae from group S1 (potentially dominant in temperate-lake species: Planktothrix agradhii, Limnothrix redekei, Pseudanabaena) can occur in quantities excluding other groups of phytoplankters, particularly in shallow, intensively mixed water bodies with usual light deficits. In shallow lakes, the success of blue-green algae from Oscillatoriales can result from the survival ability in deeper zones and the ability to grow in large numbers, as well as to replace green algae (Van den Hoeck et al. 1995). Reynolds 
Table 3. Species composition of blue-green algae in lakes of the Iławskie Lake District: Ga - Gardzień, Ił - Iławskie, Ko - Kolmowo, Si - Silm, St - Stęgwica, Ty - Tynwałdzkie

\begin{tabular}{|c|c|c|c|c|c|c|c|c|}
\hline No & Species & $\mathrm{Ga}$ & It & Ko & $\mathrm{Si}$ & St & Ty & Ecological characteristic \\
\hline 1 & Aphanizomenon flos-aquae (L.) Ralfs ex Born. et Flah. & + & + & + & + & + & + & planktic \\
\hline 2 & Aphanocapsa grevillei (Berkeley) Rabenh. & + & & & & & + & benthic \\
\hline 3 & Aphanocapsa incerta (Lemm.) Cronb. et Kom. & + & + & + & + & + & + & planktic \\
\hline 4 & Aphanothece clathrata W. et G.S. West & + & & & & & & planktic \\
\hline 5 & Aphanothece stagnina (Sprengel) A. Braun in Rabenh. & + & & & + & & & periphytic \\
\hline 6 & Chroococcus minimus (Kissl.) Lemm. & & & & & + & & planktic \\
\hline 7 & Chroococcus minutus (Kütz.) Näg. & + & & & + & + & & planktic/ periphytic \\
\hline 8 & Chroococcus limneticus Lemm. & + & + & & + & + & & planktic \\
\hline 9 & Chroococcus minor (Kütz.) Näg. & & & & & & + & periphytic \\
\hline 10 & Chroococcus turgidus (Kütz.) Näg. & + & & + & + & & + & periphytic \\
\hline 11 & Cyanothece aeruginosa (Näg.) Kom. & & + & & & & & benthic \\
\hline 12 & $\begin{array}{l}\text { Dolichospermum flos-aquae ([Lyngbye] Brébisson ex Bornet et } \\
\text { Flahault) comb. } \mathrm{n} \text {. }\end{array}$ & + & & + & & & & planktic \\
\hline 13 & Dolichospermum planctonicum (Brunnthaler) comb. $\mathrm{n}$. & + & & + & & & & planktic \\
\hline 14 & Dolichospermum solitarium (Klebahn) comb. $\mathrm{n}$. & + & & + & & & + & planktic \\
\hline 15 & Dolichospermum spiroides (Klebahn) comb. $\mathrm{n}$. & & & + & & & & planktic \\
\hline 16 & Gloeothece rupestris (Lyngbye) Bornet in Wittr. et Nordst. & & & & & & + & aerophytic \\
\hline 17 & Jaaginema woronichinii (Anis.) comb. n. Anagn. et Kom. & & & + & & & & benthic \\
\hline 18 & Jaaginema pseudogeminatum (Schmid) Anagn. et Kom. & + & & & & & & periphytic \\
\hline 19 & Leptolyngbya gelatinosa (Voronich.) Anagn. et Kom. & & & & & & + & mineral springs \\
\hline 20 & Leptolyngbya lagerheimii (Gom.) Anagn. et. Kom. & + & & & & & & planktic/ periphytic \\
\hline 21 & Limnothrix lauterbornii (Schmidle.) Anagn. & + & & + & & & + & benthic /secondary planktic \\
\hline 22 & Limnothrix planctonica (Wołosz.) Meff. & & & + & & & & planktic \\
\hline 23 & Limnothrix redekei (Van Goor) Meff. & + & + & + & + & & + & planktic \\
\hline 24 & Lyngbya martensiana Menegh. ex Gom. & + & & & & & & metaphytic/ periphytic \\
\hline 25 & Merismopedia elegans A. Braun in Kütz. & + & & & & + & & benthic \\
\hline 26 & Merismopedia glauca (Ehr.) Kütz. & & & + & & & & planktic / benthic \\
\hline 27 & Merismopedia punctata Meyen & + & & + & & & + & planktic \\
\hline 28 & Merismopedia tenuissima Lemm. & + & + & + & & + & & planktic/metaphytic \\
\hline 29 & Microcystis aeruginosa (Kütz.) Kütz. & + & + & + & + & + & + & planktic \\
\hline 30 & Microcystis firma (Kütz.) Schmid. & & & & & & + & planktic \\
\hline 31 & Microcystis flos-aquae (Wittr.) Kirchn. & & + & + & + & + & + & planktic \\
\hline 32 & Microcystis viridis (A. Br. in Rabenh.) Lemm. & + & + & + & + & + & + & planktic \\
\hline 33 & Microcystis wesenbergii (Kom.) & + & + & + & + & + & + & planktic \\
\hline 34 & Oscillatoria curviceps Agardh ex Gom. & + & & & & & & periphytic \\
\hline 35 & Oscillatoria janus Skuja & + & & + & & & + & planktic/ metaphytic \\
\hline 36 & Oscillatoria limosa Ag. ex Gom. & & + & & & + & & benthic/ periphytic \\
\hline 37 & Oscillatoria princeps Vaucher ex Gom. & + & & + & & & & benthic \\
\hline 38 & Phormidium granulatum (Gardn.) Anagn. & + & & + & & & + & benthic/epipelic \\
\hline 39 & Phormidium irriguum (Kütz. ex Gom.) Anagn. et Kom. & & & & & & + & periphytic \\
\hline 40 & Phormidium molle Gom. & & + & & & & + & periphytic/ metaphytic \\
\hline 41 & Phormidium terebriforme (Agardh ex Gom.) Anagn. et Kom. & + & & & & & + & periphytic/ benthic \\
\hline 42 & Phormidium tergestinum (Kütz.) Anagn. et Kom. & + & & + & & + & & benthic \\
\hline 43 & Planktolyngbya contorta (Lemm.) Anagn. et Kom. & + & & & + & & & planktic \\
\hline 44 & Planktolyngbya limnetica (Lemm.) Kom.-Legn.et Cronb. & + & + & + & + & + & + & planktic \\
\hline 45 & Planktothrix agardhii (Gom.) Anagn. et. Kom. & + & + & + & + & & + & planktic \\
\hline 46 & Planktothrix clathrata (Skuja) Anagn. et Kom. & + & & & & + & & planktic/benthic \\
\hline 47 & Planktothrix cryptovaginata (Škorbatov) Anagn. et Kom. & & & & & + & & periphytic \\
\hline 48 & Pseudanabaena limnetica (Lemm.) Kom. & + & + & + & + & + & + & planktic/benthic \\
\hline 49 & Pseudanabaena mucicola (Neum. et Hub.-Pest.) Schwabe & + & & + & + & + & & endogloeic/epiplanktic \\
\hline 50 & Spirulina laxa Smith & + & & & & + & & planktic \\
\hline 51 & Spirulina major Kütz. ex Gom. & & + & & & & & periphytic \\
\hline 52 & Spirulina sp. & + & & + & & & & \\
\hline 53 & Woronichinia compacta (Lemm.) Kom. et Hindi. & + & & + & + & + & + & planktic \\
\hline 54 & Woronichinia naegeliana (Unger.) Elenk. & + & + & + & + & + & + & planktic \\
\hline
\end{tabular}


(l.c.) also writes that Planktothrix agardhii can replace Microcystis aeruginosa and form a plankton of low diversity (monospecies) during conditions with light deficit.In Lake Gardzień, the average biomass of bluegreen algae during the entire research period was 39 mg. $\mathrm{l}^{-1}$, which makes up $85 \%$ of the total phytoplankton biomass (Table 4). Algal blooms in this lake are a year-round phenomenon. Only once, in December 2004, did the biomass of phytoplankton not exceed the value of $10 \mathrm{mg} \cdot \mathrm{l}^{-1}$. The maximum value of phytoplankton biomass in 2003 was recorded in September - 47.7 mg: $\mathrm{l}^{-1}$, including as much as $36.7 \mathrm{mgl}^{-1}$ of blue-green algae, mainly Planktolyngbya limnetica and Aphanizomenon flos-aquae (Fig. 1). The pronounced presence of Aphanizomenon flos-aquae in the summer probably results from higher thermal and light requirements of this species (Dokulil \& Treubner 2000). Yamamoto (2009) describes that Aphanizomenon flos-aquae usually bloomed in summer but could also tolerate low temperatures in the winter. In April, June, October and November 2003, the dominance of Limnothrix redekei was recorded. In 2004, the maximum biomass was recorded earlier, already in July. At that time, the biomass of phytoplankton reached the value of almost $176 \mathrm{mg} \cdot \mathrm{l}^{-1}$. The development of blue-green algae from the order of Chroococcales was most abundant, i.e. Woronichinia naegeliana, the biomass of which was as much as $146 \mathrm{mg}^{-1}$. A slightly lower value of blue-

Table 4. Dominant species of blue-green algae, average values of the total phytoplankton biomass $\left(\mathrm{mg} \cdot \mathrm{l}^{-1}\right)$, as well as average and maximum values of the blue-green algae biomass $\left(\mathrm{mg} \cdot \mathrm{l}^{-1}\right)$

\begin{tabular}{|c|c|c|c|c|c|c|}
\hline \multirow[b]{3}{*}{ dominants } & \multicolumn{6}{|c|}{ Lake } \\
\hline & Gardzień & Iławskie & Kolmowo & Silm & Stęgwica & Tynwałdzkie \\
\hline & 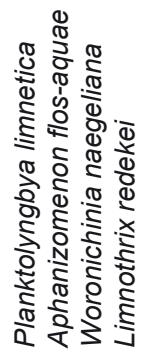 & 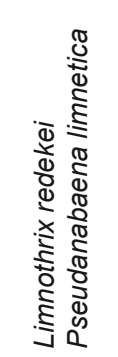 & 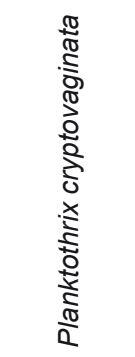 & 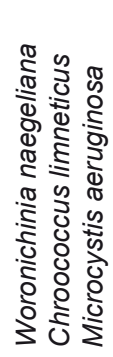 & 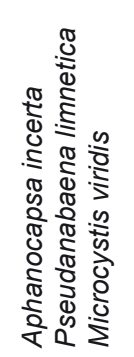 & 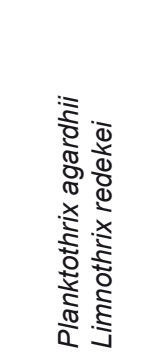 \\
\hline Average phytoplankton biomass & 46 & 25 & 56 & 4 & 9 & 75 \\
\hline Average blue-green algae biomass & 39 & 17 & 31 & 3 & 1 & 49 \\
\hline Maximum blue-green algae biomass & 164 & 37 & 111 & 10 & 6 & 133 \\
\hline
\end{tabular}

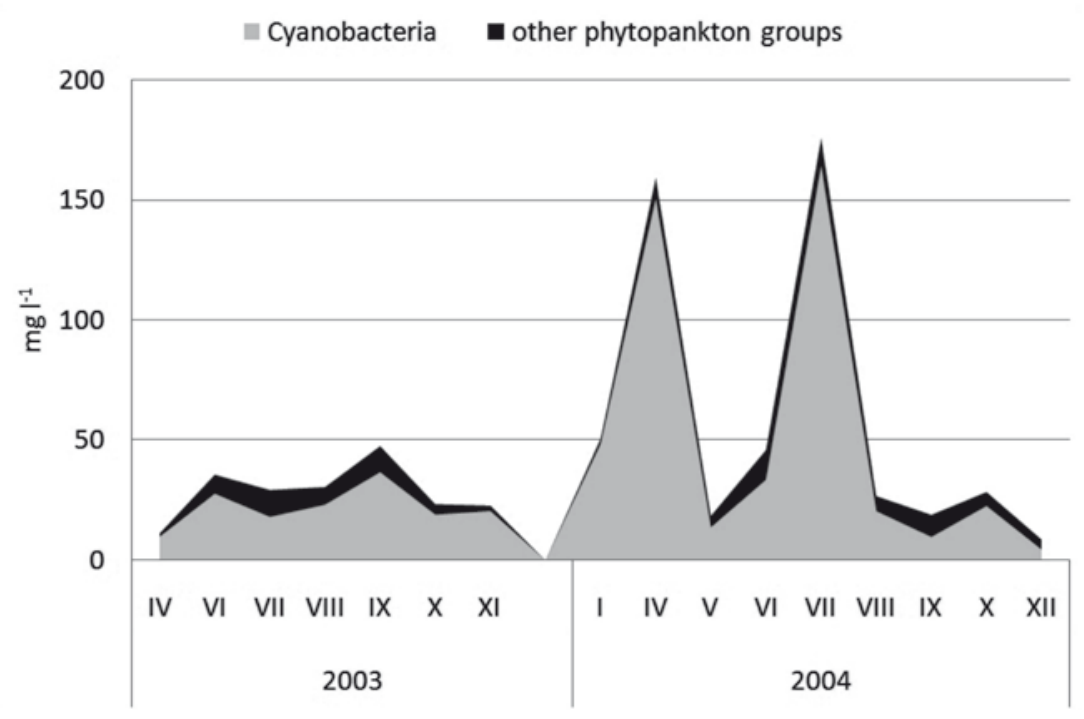

Fig. 1. Biomass $\left(\mathrm{mg} \cdot \mathrm{l}^{-1}\right)$ of Cyanobacteria and others phytoplankton groups in Lake Gardzień 
green algae biomass was recorded in April of 2004. At that time, the biomass of almost $150 \mathrm{mg} \cdot \mathrm{l}^{-1}$ was made up by filamentous Limnothrix redekei. In spring and autumn, and even in winter (beneath the ice), species of Oscillatoriales dominated among blue-green algae: apart from Limnothrix redekei, also Planktolyngbya limnetica. Based on German research conducted in shallow lakes, Mischke (2003) reports that Limnothrix redekei develops in the largest numbers in winter and spring. These data indicate the preferences of this species for low temperatures. The situation in Lake Gardzień was similar to German studies. At that time, Aphanizomenon flos-aquae and Pseudanabaena limnetica occurred in smaller, but also significant quantities. The concentration of chlorophyll $a$ was monitored in this lake starting from June 2003 to May 2004. The average value of the chlorophyll $a$ concentration was $42.3 \mu \mathrm{g} \cdot \mathrm{l}^{-1}$ and ranged from $22.0 \mu \mathrm{g} \cdot \mathrm{l}^{-1}$ to $73.2 \mu \mathrm{g} \cdot \mathrm{l}^{-1}$. The concentration of chlorophyll $a$ was three times higher than the value of $50 \mu \mathrm{g} \cdot \mathrm{l}^{-1}$. This took place in September 2003, January and April 2004.

Studies on water blooms in Lake Iławskie were conducted only for one season, i.e. from April 2002 to November 2002 and in February 2003. During that time, the average biomass of phytoplankton (Table 4) came to almost $25 \mathrm{mgl}^{-1}$, including the biomass of blue-green algae, which constituted $17 \mathrm{mg}^{-1}$ (i.e. 67\%). The maximum value of blue-green algae biomass was recorded in September 2002, when almost $36 \mathrm{mg}^{-1} \mathrm{of}^{-1}$ the biomass was made up by Pseudanabaena limnetica (Fig. 2). In this lake, water blooms of blue-green al- gae were not recorded only in the coldest months - in April 2002 and January 2003. At that time, the biomass of blue-green algae was insignificant, below $1 \mathrm{mg} \cdot \mathrm{l}^{-1}$, with the dominant species Limnothrix redekei. In the remaining lakes, cyanobacterial blooms occurred, and their biomass ranged from 13 to $37 \mathrm{mg} \cdot \mathrm{l}^{-1}$. These algal blooms were created by Limnothrix redekei in June, and in the subsequent months by Pseudanabaena limnetica.

The average biomass of phytoplankton in Lake Kolmowo (Table 4) was almost $56 \mathrm{mg} \cdot \mathrm{l}^{-1}$, including the biomass of blue-green algae, which constituted $31 \mathrm{mgl}^{-1}$ (i.e. 56\%). In Lake Kolmowo, cyanobacterial blooms were observed from June to October. Outside these months, the contribution of blue-green algae in the phytoplankton reached just a few percent at most. The maximum values of blue-green algae (109 $\left.\mathrm{mg} \mathrm{l}^{-1}\right)$ in this lake were recorded in September 2002 and in August $2003\left(111 \mathrm{mg}^{-1}\right)$, when almost $100 \%$ of them were filamentous blue-green algae Planktothrix cryptovaginata (Fig. 3). It is a metaphyton and tychoplankton species (Wehr \& Sheath 2003, Komárek \& Komárkowa 2004). The mass development of this blue-green alga in the plankton can be related to vertical migrations in the summer, with considerable light deficiency.

In Lake Swarzędzkie, as in Lake Kolmowo, algal blooms occur also in September. Stefaniak et al. (2007) report that algal blooms of filamentous blue-green algae Planktothrix agardhii and Limnothrix redekei reach the value of $52 \mathrm{mgl}^{-1}$. In Lake Kolmowo, the concen-

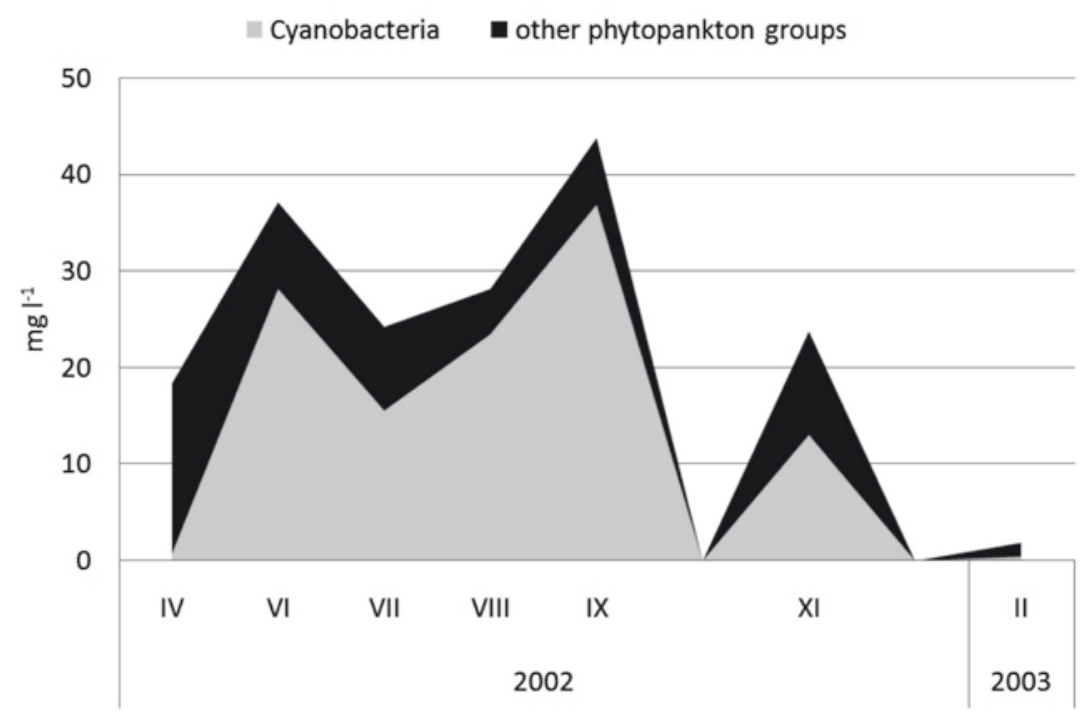

Fig. 2. Biomass (mg $\mathrm{l}^{-1}$ ) of Cyanobacteria and others phytoplankton groups in Lake Iławskie 


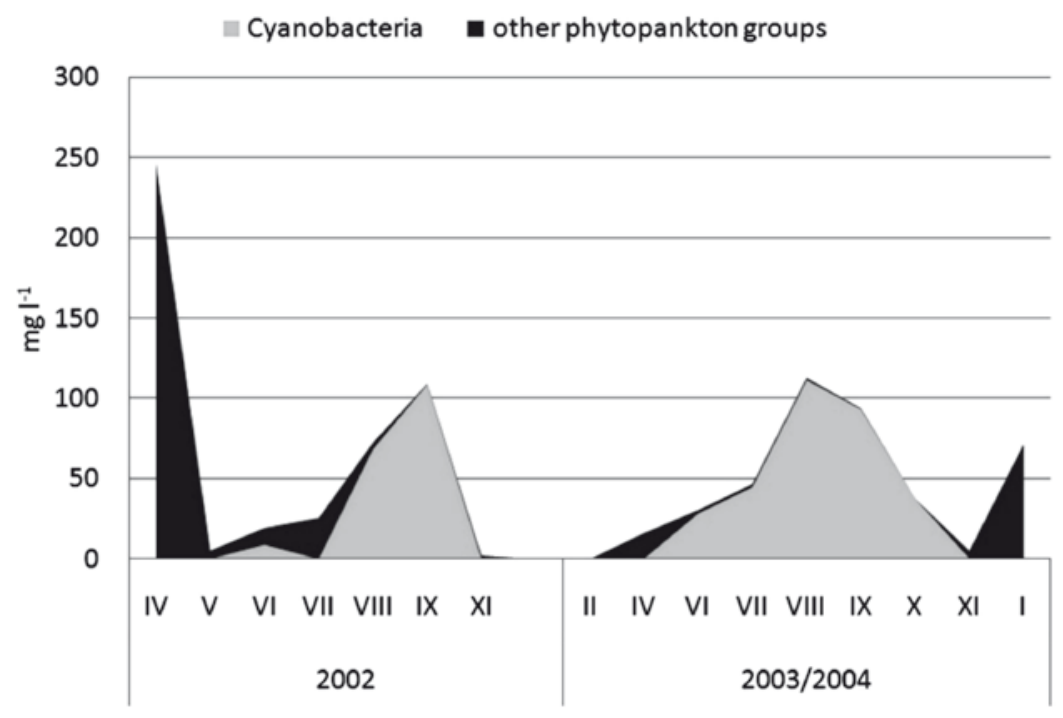

Fig. 3. Biomass $\left(\mathrm{mgl}^{-1}\right)$ of Cyanobacteria and others phytoplankton groups in Lake Kolmowo

tration of chlorophyll $a$ was investigated from June 2003 to January 2004. The average value of the chlorophyll $a$ concentration was $40.3 \mu \mathrm{g} \cdot \mathrm{l}^{-1}$ and it ranged from $5.8 \mu \mathrm{g} \cdot \mathrm{l}^{-1}$ to $105.3 \mu \mathrm{g} \cdot \mathrm{l}^{-1}$. The concentration of chlorophyll $a$ exceeded the value of $50 \mu \mathrm{g}^{-1}$ only in September 2003, when it reached the maximum value.

The average biomass of phytoplankton in Lake Silm was $4.1 \mathrm{mg} \mathrm{l}^{-1}$ (Table 4 ), including the biomass of blue-green algae of $2.8 \mathrm{mg} \mathrm{l}^{-1}$ (i.e. $70 \%$ ). In Lake Silm, cyanobacterial bloom was observed in August 2005 (Fig. 4). It was a mixed water bloom with the dominant species: Woronichinia naegeliana, Chroococ- cus limneticus and Microcystis aeruginosa. During that month, the biomass of phytoplankton was $11.5 \mathrm{mg} \cdot \mathrm{l}^{-1}$, including $10.0 \mathrm{mg} \cdot \mathrm{l}^{-1}$ of blue-green algae. Species of Chroococcales are less common in intensively mixed zones; therefore it is likely that in Lake Silm the conditions for stabilisation of water masses occur more often and for a longer time, as compared to other studied lakes. Probably, such conditions result from the location of this reservoir in the forest and more effective protection against wind mixing. In the other months, the biomass of phytoplankton did not exceed $10 \mathrm{mg} \cdot \mathrm{l}^{-1}$. Nevertheless, the proportion of blue-green

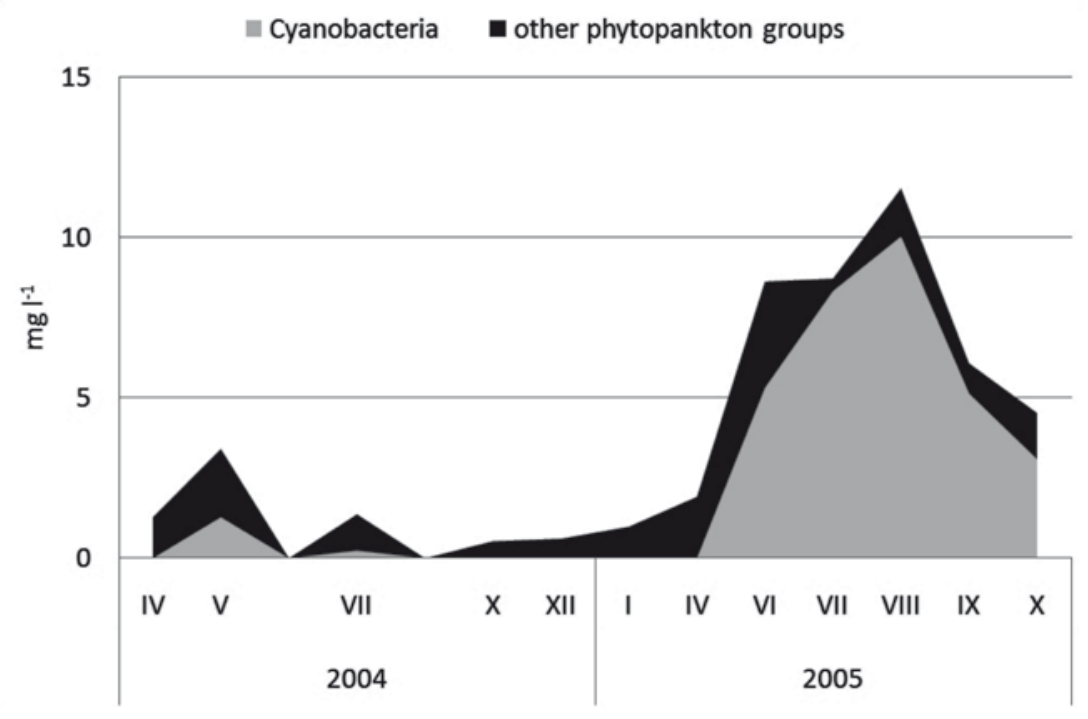

Fig. 4. Biomass $\left(\mathrm{mg}^{-1} \mathrm{l}^{-1}\right.$ of Cyanobacteria and others phytoplankton groups in Lake Silm 
algae in phytoplankton in the summer was considerable. In the summer of 2005 from June to September, the average biomass of phytoplankton was $8.7 \mathrm{mg} \cdot \mathrm{l}^{-1}$, and blue-green algae $7.2 \mathrm{mg}^{-1}$. It makes up $83 \%$ of blue-green algae in the summer and can give a negative forecast for the future, especially that the dominant blue-green algae were as follows: Woronichinia naegeliana, Microcystis aeruginosa and Microcystis wesenbergii. Interestingly enough, in water bodies of southern Poland, Woronichinia naegeliana tends to be found in autumn at temperatures below $15^{\circ} \mathrm{C}$ (Bucka \& Wilk-Woźniak 2005). Microcystis aeruginosa is reported from water reservoirs situated in agricultural areas (Bucka \& Wilk-Woźniak 1.c.), whereas Lake Silm is situated in a forest drainage basin.

In the phytoplankton of Lake Stęgwica, the average biomass of phytoplankton (Table 4) came to almost $8.8 \mathrm{mg} \mathrm{l}^{-1}$, whereas the average contribution of bluegreen algae was just $1.1 \mathrm{mg} \mathrm{l}^{-1}$. In this lake, cyanobacterial blooms occurred only twice - in August of 2002 and September/October of 2003. (Fig. 5). At that time, blue-green algae made up 52\% of the whole phytoplankton biomass. Aphanocapsa incerta, Pseudanabaena limnetica and Microcystis viridis dominated in this lake. The concentration of chlorophyll $a$ was studied from June 2003 to January 2004. The average value of the chlorophyll $a$ concentration was $10.3 \mu \mathrm{g}^{-1}$ and it ranged from $4.8 \mu \mathrm{g} \cdot \mathrm{l}^{-1}$ to $14.8 \mu \mathrm{g} \cdot \mathrm{l}^{-1}$. It seems that the considerable proportion of blue-green algae in Lake Stegwica was an insignificant phenomenon and algal blooms do not pose a threat to the functioning of this water body.
The average biomass of phytoplankton in Lake Tynwałdzkie (Table 4) was $75 \mathrm{mg} \cdot \mathrm{l}^{-1}$, and the average blue-green algae biomass was $49 \mathrm{mgl}^{-1}$ (i.e. 66\%). The maximum values of blue-green algae biomass (Fig. 6) were recorded in July 2002 (i.e. $133 \mathrm{mg} \cdot \mathrm{l}^{-1}$ - Planktothrix agardhii dominating in 88\%), in June 2003 (83 mg. $\mathrm{l}^{-1}$, including $82 \%$ Limnothrix redekei) and interestingly enough, in January $2004\left(84 \mathrm{mg} \cdot \mathrm{l}^{-1}\right.$, including 60\% Planktothrix agardhii, and 37\% Limnothrix redekei). Kozak et al. (2007) report even higher values of cyanobacteria during water blooms in the Maltański Reservoir. In August, the biomass of blue-green algae Planktothrix agardhi, Pseudanabaena limnetica, Anabaena (Dolichospermum) spiroides and/or Anabaena (Dolichospermum) flos-aquae reached the value of 186 $\mathrm{mg} \cdot \mathrm{l}^{-1}$. In Lake Tynwałdzkie, algal blooms occur almost all the time. Only in February of 2003, the value of the phytoplankton biomass was very low $-0.3 \mathrm{mg} \cdot \mathrm{l}^{-1}$. Also the biomass of blue-green algae at the beginning of 2003, i.e. in February and in April, was very low. Nevertheless, the phytoplankton bloom occurred in April of 2003, but it appeared due to the abundant development of centric diatoms. On other dates, cyanobacteria are responsible for algal blooms. The results of the research on phytoplankton in Lake Tynwałdzkie from 1991 obtained by Luścińska \& Dogadalska (1993) were compared with the results obtained 15 years previously by Bogaczewicz-Adamczak (1978). In 1972, the abundant development of two algal taxa from the class of Chrysophyceae was observed in spring, which in the 1990s was replaced by coccal green algae char-

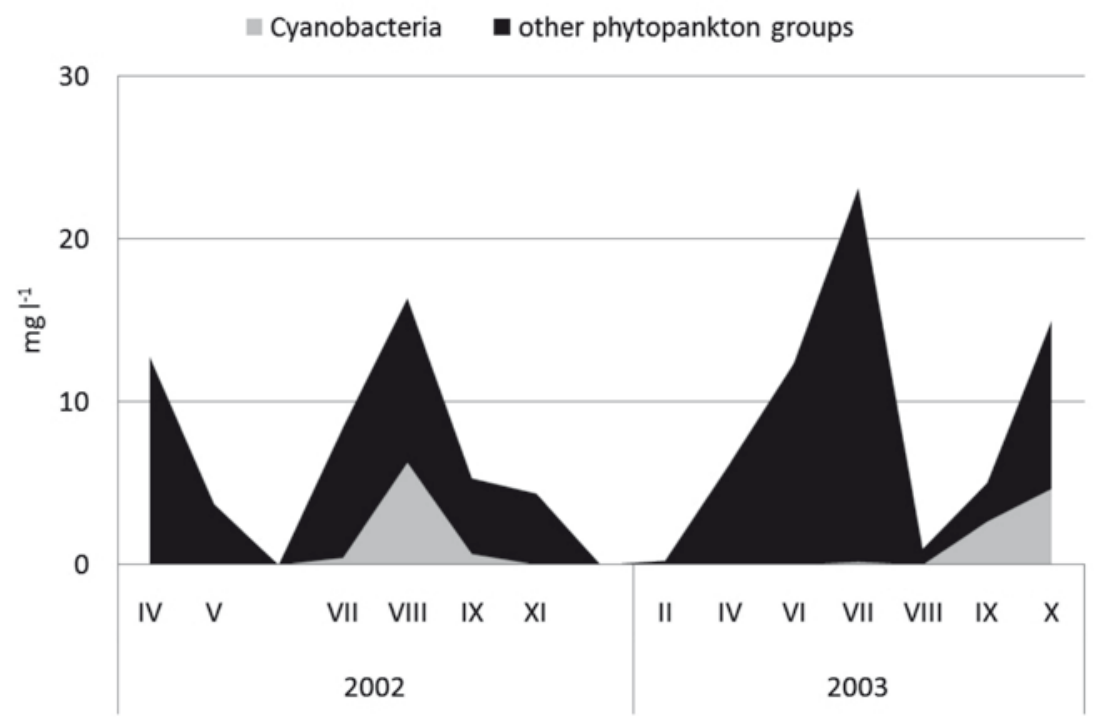

Fig. 5. Biomass $\left(\mathrm{mg} \cdot \mathrm{l}^{-1}\right.$ ) of Cyanobacteria and others phytoplankton groups in Lake Stęgwica 


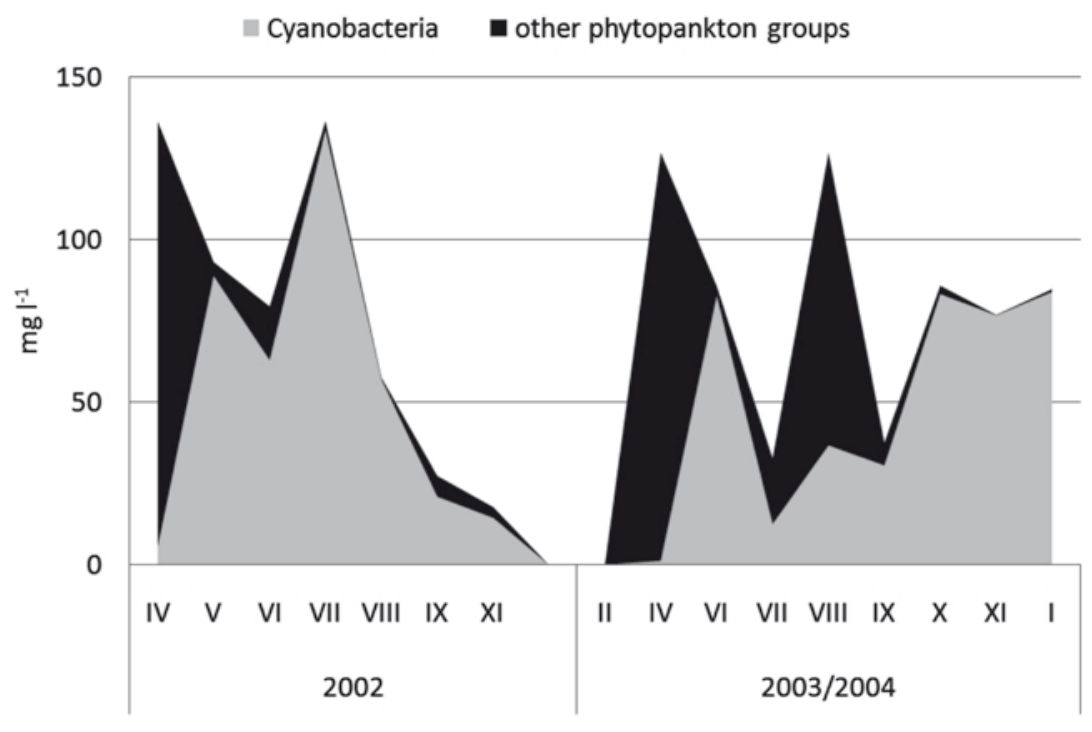

Fig. 6. Biomass $\left(\mathrm{mg} \cdot \mathrm{l}^{-1}\right.$ ) of Cyanobacteria and other phytoplankton groups in Lake Tynwałdzkie

acteristic of polytrophic water bodies. In the phytoplankton from 2002-2003, cyanobacteria were the definitive dominants. The above-described changes in the dominance structure of algae in the plankton of Lake Tynwałdzkie prove that the trophic level of lake waters is still increasing. In this lake, the concentration of chlorophyll $a$ was monitored from June 2003 to January 2004. The average value of the chlorophyll a concentration was $74.1 \mu \mathrm{g} \cdot \mathrm{l}^{-1}$ and it ranged from 41.6 $\mu \mathrm{g} \cdot \mathrm{l}^{-1}$ to $117.1 \mu \mathrm{g} \cdot \mathrm{l}^{-1}$. The concentration of chlorophyll $a$ fell below the value of $50 \mu \mathrm{g} \cdot \mathrm{l}^{-1}$ only twice. This took place in June and August of 2003.

In all the studied lakes, the maximum values of blue-green algae biomass were recorded in the summer months, usually late summer. Optimal conditions for the growth of blue-green algae are at the temperature of ca. $25^{\circ} \mathrm{C}$, and then algal blooms can develop (Kobos et al. 2005).

The studied lakes can be arranged in respect of the size and duration of cyanobacterial blooms. The longest algal blooms occur in Lake Gardzień; they last almost throughout the year. In this reservoir, the maximum biomass values for cyanobacteria were also the highest ones. The duration of algal blooms in Lake Tynwałdzkie is a bit shorter; values for the maximum biomass of cyanobacteria are also smaller, but the average values of cyanobacteria biomass are the highest among the studied lakes. Lake Kolmowo comes third with blooms continuing for half a year. In this lake, the intensive development of phytoplankton is also reflected in a very high value of the average and maxi- mum biomass. Lake Iławskie had much lower values of the maximum and average cyanobacteria biomass compared to other lakes. The research was carried out, however, for a considerably shorter time, i.e. for just seven months. Incidental algal blooms occur in Lake Stęgwica and Lake Silm.

Lakes with permanent algal blooms are characterised by a considerable contribution of cyanobacteria from the order of Oscillatoriales. According to Dokulil \& Teubner (2000), these species - tolerant to mixing - do not have the ability of $\mathrm{N}_{2}$ assimilation, they are not subjected to stratification and they do not migrate. According to Rücker et al. (1997), lakes of this type are characterised by a low average depth $\left(\mathrm{z}_{\max }<3 \mathrm{~m}\right)$ and low transparency $(<0.3 \mathrm{~m})$, and are called "Oscillatoriaceae lakes". Depending on the dominant species and the dynamics of water masses, these authors classify such lakes into two types: "Planktothrix-lakes", where the influence of disturbances (turbulence) is stronger and "Limnothrix-lakes", where the influence of wind is less. Mischke (2003) quotes the results of field and experimental studies by Wiedner (1999) which confirm that Planktothrix is a more tolerant species to water mixing compared with Limnothrix and Pseudanabaena. This tolerance to mixing provides the possibility of faster trapping of phosphorus that reaches the pelagic zone "in pulses" during resuspension. In the case of Iławskie Lakes, Lakes Tynwałdzkie and Kolmowo can be classified as "Planktothrix-lakes". These two lakes are situated within an open territory surrounded by arable fields. Certainly, the water mixing intensity in 
both lakes is strongly affected by wind. Unfortunately, the abundant development of Planktothrix influences the considerable production of microcystins (Mischke 2003). Among the studied lakes, Lakes Tynwałdzkie and Kolmowo are also included among lakes with the highest trophic status. The average value of the TSI coefficient comes to 68 for Lake Kolmowo and 69 for Lake Tynwałdzkie.

Lakes Iławskie and Gardzień can be classified as "Limnothrix-lakes". These reservoirs are characterised by high shores. Lake Gardzień is particularly protected against wind, because it is situated in a valley overgrown with forest. Probably in these water bodies, the influence of wind on water mixing is limited. The trophic level of these water reservoirs is also lower than in the case of the previous ones, and comes to 66 for Lake Iławskie and 64 for Lake Gardzień.

The state of the ecosystems in Lakes Silm and Stęgwica does not appear to be endangered. In these water bodies, algal blooms were occasional phenomena. In Lake Silm, the intensive development of blue-green algae was recorded four times a year. The amount of biomass was reflected in the water bloom only once. A similar situation was observed in Lake Stęgwica, where the increased contribution of bluegreen algae was recorded just twice. Both lakes are situated in a forest drainage basin, and the forests protect the lakes against the excessive supply of nutrients. Despite the fact that the trophic status of both lakes is relatively high (the average value of TSI - 59 for Lake Silm and 61 for Lake Stęgwica), these lakes are, however, characterised by a small proportion of blue-green algae in phytoplankton. In the case of Lake Stęgwica, this obviously results from a high content of humus compounds. According to Starmach et al. (1976), the presence of a large amount of humus substances limits the development of some algae, i.a. blue-green algae.

The research on shallow lakes reveals a close relationship between the species composition of a water bloom, its intensity and duration, and the trophic state of a reservoir and the nature of a drainage basin. The ratio N:P in the studied lakes was high enough to prevent the mass occurrence of N-fixing cyanobacteria from the order of Nostocales. This high level of $\mathrm{N}: \mathrm{P}$ is suitable for cyanobacteria Chroococcales, but their occurrence is also determined by stable conditions, i.e. no water mixing. Hence their periodic presence in lakes Silm, Stęgwica and Gardzień, whose direct catchment area is overgrown with forest reducing water mixing. Consequently, a combination of suitable conditions, i.e. high dynamics and a high level of biogenic substances in the remaining lakes, determines the characteristic species composition, with the dominance of Oscillatoriales incapable of assimilating atmospheric nitrogen and favouring intensively mixed water bodies.

This high biomass of phytoplankton with a particularly high contribution of blue-green algae negatively influences the whole ecosystem. The main problem is related to an extremely high production of organic matter, which during the processes of decomposition induces intensive oxygen consumption. In turn, the oxygen deficits affect the course of chemical processes taking place in the water. Animals are particularly exposed to cyanobacterial water blooms, due to the fact that species such as Aphanizomenon flos-aquae, Planktothrix agardhii, Planktothrix cryptovaginata, Microcystins aeruginosa, and Woronichinia naegeliana are potential producers of toxins. Toxins can be accumulated in animal bodies; therefore indirectly the problem may also affect humans. Among the studied water basins, Lake Tynwałdzkie is overexploited in terms of fishing, and Lakes Kolmowo and Iławskie constitute watering places for farm animals.

In the end, algal blooms prevent the development of submerged vegetation, which would stabilize the bottom sediments and would constitute an additional "consumer" of biogenic substances, and thus it would control the biocenotic relations in these lakes. Unfortunately, the long-term dominance of bluegreen algae occurring in shallow lakes of the Iława Lake District may be difficult to eliminate if modern methods of lake reclamation are applied.

\section{References}

Berg K., Carmichael W.W., Skulberg O.M., Benestad C., Underdal B., 1987, Investigation of a toxic-water bloom of Microcystis aeruginosa (Cyanophyceae) in Lake Akersvatn, Norway, Hydrobiologia 144: 97-103.

Bogaczewicz-Adamczak B., 1978, The structure and production of phytoplankton in Lake Tynwałd, Arch. Hydrobiol.- Algol. Stud. 20: 328-36.

Bucka H., 1987, Ecological aspects of the mass appearance of planktonic algae in the dam reservoirs of southern Poland, Acta Hydrobiol., 29(2): 149-91.

Bucka H., Wilk-Woźniak E., 2005, A contribution to the knowledge of some potentially toxic cyanobacteria species forming blooms in water bodies - chosen examples, Oceanol. Hydrobiol. Stud. 34(Suppl.3): 43-53.

Carlson R.E., 1977, A Trophic State Index for Lakes, Limnology and Oceanography 22: 61-369. 
Carlson R.E., Simpson J., 1996, Coordinator's Guide to Volunteer Lake Monitoring Methods, North American Lake Management Society, http://dipin.kent.edu/tsi. htm.

Carmichael, W.W., 1994, The toxins of cyanobacteria. Sci. Am. J. 270: 78-86.

Carmichael W.W., 1996, Toxic Microcystis and the environment, [in:] Watanabe M.F., Harada K.I., Carmichael W.W., Fujiki H. (eds) Toxic Microcystis, CRC Press, Boca Raton, p. 1-11.

Codd GA., 2000, Cyanobacterial toxins, the perception of water quality, and the prioritisation of eutrophication control, Ecol. Eng. 6: 51-60.

Dokulil M.T., Teubner K., 2000, Cyanobacteria dominance in lakes, Hydrobiologia 438: 1-12.

Hermanowicz W., Dożańska W., Dojlido I., Koziorowski B., Zerbe J., 1999, Fizyczno-chemiczne badanie wody i ścieków (Physico-chemical investigations of water and sewages), Arkady, Warszawa, pp. 556 (in Polish).

Jańczak J. (ed.), 1997, Atlas jezior Polski. T. 2 (The atlas of lakes in Poland. Vol. 2), Bogucki Wyd. Nauk., Poznań, pp. 268 (in Polish).

Kobos J., Mazur-Marzec H., Dittmer M., Witek B., Pliński M., 2005, Toxic cyanobacterial blooms in the Kociewskie Lakes (Northern Poland), Oceanol. Hydrobiol. Stud. 34(Suppl. 3): 77-84.

Komárek J., Komárková J., 2004, Taxonomic review of the cyanoprokaryotic genera Planktothrix and Planktothricoides, Czech Phycology 4: 1-18.

Kozak A., Gołdyn R., Tymek K., 2007, Long-term changes in the phytoplankton of a shallow storage reservoir, Oceanol. Hydrobiol. Stud. 36(Suppl.1): 87-93.

Kratzer C.R., Brezonik P.L., 1981, A Carlson-type trophic state index for nitrogen in Florida lakes, Water. Res. Bull. 17: 713-15.

Luścińska M., Dogadalska E., 1993, The structure of phytoplankton communities in Lake Tynwałd, Limnol. Pap.18: 54-62.

Mischke U., 2003, Cyanobacteria associations in shallow polytrophic lakes: influence of environmental factors, Acta Oecol. 24: S11-S23.

Mischke U., Nixdorf B., 2003, Equilibrium phase conditions in shallow German lakes: How Cyanoprocaryota species establish a steady state phase in late summer, Hydrobioogia 502: 123-32.

Nusch E. A., 1980, Comparison of different methods for chlorophyll and phaeopigment, Arch. Hydrobiol. Beih. Ergebn. Limnol. 14: 14-16.
Rejewski M., 1979, The structure and function of macrophytic communities in two eutrophic lakes in the Iława Lake District, Limnol. Pap.11: 19-34.

Reynolds C.S., Oliver R.L., Walsby A.E., 1987, Cyanobacterial dominance: the role of buoyancy regulation in dynamic lake environments, New Zeal. J. Mar. Fresh. Res. 21: 379-90.

Reynolds C.S., 2006, Ecology of Phytoplankton, Cambridge University Press, Cambridge, pp. 535.

Rücker J., Wiedner C., Zippel P., 1997, Factors controlling the dominance of Planktothrix agardhii and Limnothrix redeckei in eutrophic shallow lakes. Hydrobiologia 342/43: 107-15.

Scheffer M., Jeppesen E., 1998, Alternative stable state, [in:] Scheffer M., Ecology of shallow lakes, Chapman and Hall, London, pp. 357.

Starmach K., Wróbel S., Pasternak K., 1976, Hydrobiologia. Limnologia (Hydrobiology. Limnology), PWN, Warszawa, pp. 621 (in Polish).

Stefaniak K., Gołdyn R., Kowalczewska-Madura K., 2007, Changes of summer phytoplankton communities in Lake Swarzędzkie, Oceanol. Hydrobiol. Stud. 36(Suppl. 1): 77-85.

Utermöhl H., 1958, Zur Vervollkommnung der quantitativen Phytoplankton - Methodik, Mitt. Int. Ver. Limnol. 9: 1-38.

Van den Hoek C., Mann D.G., Jahns H.M., 1995, Algae. An introduction to phycology, Cambridge University Press, Cambridge, pp. 627.

Van Donk E., Smolders A.J.P., Mulderij G., 2002, Stratoides aloides L. inhibits algal growth [Abstract], [in:] Shallow Lakes 2002. International Conference on Limnology of Shallow Lakes, Balatonfüred, Hungary 25-30 May (2002), Veszprm University Press.

Wallace B.B., Bailey M.C., Hamilton D.P., 2000, Simulation of vertical position of buoyancy regulating Microcysis aeruginosa in shallow eutrophic lake, Aquat. Sci. 62: 320333.

Wehr J.D., Sheath R.G., 2003, Freshwater algae of North America: ecology and classification, Academic Press, San Diego, pp. 950.

Yamamoto Y., 2009, Environmental factors that determine the occurrence and seasonal dynamics of Aphanizomenon flos-aquae, J. Limnol. 68(1): 122-132. 